\title{
SUSCEPTIBILITY OF ER YTHROCEBUS PATAS MONKEYS TO RUBELLA VIRUS
}

\author{
C. C. Draper* and Gwenneth D. Laurence \\ Wellcome Research Laboratories, Beckenham, Kent
}

\begin{abstract}
Although multiplication of rubella virus has been shown to occur in hamsters, ferrets and rabbits (Oxford, 1967), in some species of rats (Cotlier et al., 1968), and in suckling mice (Carver et al., 1967), monkeys remain the most suitable laboratory animals for certain in-vivo studies, such as the preliminary evaluation of vaccine strains for their use in man. Successful infection of African green monkeys has been reported (Sigurdardottir et al., 1963; Cabasso et al., 1967), but in all extensive studies rhesus monkeys have been used (Parkman et al., 1965, 1967; Sever et al., 1966; Cabasso et al.). One unsuccessful attempt to infect cynomolgus monkeys has been reported (Krugman et al., 1953). This note describes experiments to test the susceptibility of patas monkeys (Erythrocebus patas).
\end{abstract}

\section{Methods}

Patas monkeys were held in quarantine for several months after arrival from West Africa and were then checked for the absence of antibodies to rubella virus. Two groups, each consisting of 6 monkeys, were housed in two separate rooms; 5 monkeys of each group were inoculated either intravenously (i.v.) or intramuscularly (i.m.), as shown in table I, with different strains of rubella virus. The uninoculated monkey in each group was kept in close proximity to the others to test for possible contact infection. The HPV77 attenuated strain of rubella virus (Parkman et al., 1965) was kindly provided by Dr H. M. Meyer and had undergone two further passages in primary patas kidney cell cultures in our laboratory. The Sheppard strain of virus, kindly provided by Dr J. A. Dudgeon, was a recent isolate from a human case of rubella, and had undergone a total of 6 passages in RK13 tissue cultures. One $\mathrm{ml}$ of either strain was inoculated i.v. or i.m. and immediately afterwards the preparations were titrated to determine the dose of viable virus given. Thereafter, at 2-3day intervals, the monkeys were bled under phencyclidine sedation from the femoral vein and throat, nasal and rectal swabs were also taken. The swabs were at once immersed in $2 \mathrm{ml}$ of cold tissue-culture medium containing antibiotics and 0.75 per cent. bovine albumin. $0.25 \mathrm{ml}$ of the serum or of the swab specimens, kept on ice since collection, was inoculated within a few hours into each of 3 culture tubes of primary patas monkey kidney, and the remainder stored at $-70^{\circ} \mathrm{C}$ for further isolation attempts. The cultures were incubated on roller drums at $35^{\circ} \mathrm{C}$ and the medium was changed after 6 days. After 10 days the medium was harvested and the culture challenged with about $10^{3}$ TCD50 of the bovine enterovirus M6. The identity of rubella virus in a few of the cultures showing interference to the M6 virus was confirmed by neutralisation of the harvested fluids by a specific antiserum. No specimen was considered to be negative until a passage had been done of the fluids harvested at 10 days into fresh tissue cultures; these were challenged as above. An adenovirus was

Received 9 Oct. 1968; accepted 5 Nov. 1968.

* Present address: London School of Hygiene and Tropical Medicine, Keppel Street, Gower Street, London, W.C.1.

J. MED. MICROBIOL.-VOL. 2 (1969) 
present in some of the rectal swabs taken from monkeys 7 to 12 , which necessitated treatment of the specimens, and of the fluids used for passage, with a specific antiserum. Some of the sera were tested for rubella haemagglutination-inhibiting (HI) antibodies by published methods (Stewart et al., 1967), with the use of kaolin treatment of the sera and an etherextracted antigen from BHK21 cells, but with pigeon red blood cells instead of day-old chick cells as the indicator system.

\section{RESULTS}

The results of the virus isolation and antibody studies are shown in tables I and II. After i.v. or i.m. inoculation with a wild strain of virus the patas

\section{TABLE I}

Days after inoculation on which rubella virus was isolated from patas monkeys

\begin{tabular}{|c|c|c|c|c|c|}
\hline \multirow{2}{*}{$\begin{array}{l}\text { Monkey } \\
\text { no. }\end{array}$} & \multirow{2}{*}{$\begin{array}{l}\text { Virus inoculated, dose } \\
\text { and route }\end{array}$} & \multicolumn{4}{|c|}{ Days on which virus isolated from } \\
\hline & & blood & throat & nose & rectum \\
\hline $\begin{array}{l}1 \\
2 \\
3 \\
4 \\
5 \\
6\end{array}$ & $\begin{array}{l}\text { None } \\
\text { HPV77 104.0 TCD50 i.v. } \\
\text { HPV77 104.0 TCD50 i.v. } \\
\text { HPV77 104.0 TCD50 i.v. } \\
\text { HPV77 104.0 TCD50 i.m. } \\
\text { HPV77 104.0 TCD50 i.m. }\end{array}$ & $\begin{array}{l}\cdots \\
\cdots \\
\cdots \\
\cdots \\
\cdots\end{array}$ & $\begin{array}{r}\cdots \\
\ldots \\
\cdots \\
9 \\
9 \\
12\end{array}$ & $\begin{array}{c}\cdots \\
\cdots \\
\cdots \\
\ldots \\
5,7,9,12,14,16\end{array}$ & $\begin{array}{l}\cdots \\
\cdots \\
\cdots \\
\cdots \\
\cdots\end{array}$ \\
\hline $\begin{array}{r}7 \\
8 \\
9 \\
10 \\
11 \\
12\end{array}$ & $\begin{array}{l}\text { None } \\
\text { Sheppard } 10^{6.0} \text { TCD50 i.v. } \\
\text { Sheppard } 10^{6.0} \text { TCD50 i.v. } \\
\text { Sheppard } 10^{6.0} \text { TCD50 i.v. } \\
\text { Sheppard } 10^{6.0} \text { TCD50 i.m. } \\
\text { Sheppard } 10^{6.0} \text { TCD50 i.m. }\end{array}$ & $\begin{array}{c}\ldots \\
\dddot{9}^{*} \\
9^{*} \\
\dddot{16}^{*}\end{array}$ & $\begin{array}{l}7^{*}, 9,12,14^{*}, 16 \\
12,14^{*}, 16 \\
9,12,14 \\
9 *, 12 \\
9,16\end{array}$ & $\begin{array}{l}5,7^{*}, 9,12,14,16 \\
9^{*}, 14,16 \\
5,9,12,14,16 \\
9,12,14,16^{*}\end{array}$ & $\begin{array}{l}7^{*}, 9,12 \\
9^{*}, 16 \\
7,9 \\
\quad \ldots \\
9,12,16\end{array}$ \\
\hline
\end{tabular}

$*$ = Virus isolated only after 2 nd passage of specimen.

monkeys showed prolonged excretion of the virus from the nasopharynx and rectum. Rectal swabs were taken up to 30 days after inoculation, but nose and throat swabs were not taken after the 16th day, and it is possible that virus excretion by these routes may have continued longer. There was no evidence of spread of infection to the uninoculated monkey. None of the monkeys showed symptoms of disease other than slight lymphadenopathy in some of them. Daily records of rectal temperatures and periodic white blood cell counts were also done, but there was no common pattern of response. The reactions to the attenuated virus were more irregular: all the inoculated monkeys became infected, as shown by the development of antibodies, but the virus was isolated from only 3 animals, although in one instance (no. 6) excretion from the nose continued over a period of at least 11 days. The titres of antibodies in this small series were generally lower than with the wild virus. Again no clinical signs were observed, and there was no spread to the uninoculated monkey. 


\section{Discussion}

Although a large dose of the wild virus was given, the evolution of infection in patas monkeys appears to have been slightly delayed in comparison with rhesus monkeys. In the latter species viraemia has been reported over days 2-11 after inoculation with a wild virus, and nasopharyngeal and rectal excretion over days 4-11, with one instance of excretion to day 17 (Parkman et al., 1965, 1967). Some of these differences may be related to variations in technique. Except for the absence of clinical signs, the virological events resembled those in man after infection with rubella. Similar differences between

TABLE II

Titres of rubella HI antibodies in blood of patas monkeys

\begin{tabular}{|c|c|c|c|c|c|}
\hline \multirow{2}{*}{ Monkey no. } & \multirow{2}{*}{$\begin{array}{l}\text { Virus inoculated and } \\
\text { route }\end{array}$} & \multicolumn{4}{|c|}{ Titre at day after inoculation } \\
\hline & & 0 & 12 & 37 & 71 \\
\hline $\begin{array}{l}1 \\
2 \\
3 \\
4 \\
5 \\
6\end{array}$ & $\begin{array}{l}\text { None } \\
\text { HPV77 i.v. } \\
\text { HPV77 i.v. } \\
\text { HPV77 i.v. } \\
\text { HPV77 i.m. } \\
\text { HPV77 i.m. }\end{array}$ & $\begin{array}{l}<8 \\
<8 \\
<8 \\
<8 \\
<8 \\
<8\end{array}$ & $\begin{array}{l}<8 \\
<8 \\
16 \\
<8 \\
<8 \\
<8\end{array}$ & $\begin{array}{r}<20 \\
64 \\
16 \\
16 \\
16 \\
32\end{array}$ & $\begin{array}{r}\text { NT } \\
32 \\
16 \\
32 \\
8 \\
32\end{array}$ \\
\hline $\begin{array}{r}7 \\
8 \\
9 \\
10 \\
11 \\
12\end{array}$ & $\begin{array}{l}\text { None } \\
\text { Sheppard i.v. } \\
\text { Sheppard i.v. } \\
\text { Sheppard i.v. } \\
\text { Sheppard i.m. } \\
\text { Sheppard i.m. }\end{array}$ & $\begin{array}{l}<8 \\
<8 \\
<8 \\
<8 \\
<8 \\
<8\end{array}$ & $\begin{array}{l}<8 \\
\text { NT } \\
<8 \\
<8 \\
<8 \\
64\end{array}$ & $\begin{array}{r}<8 \\
64 \\
64 \\
64 \\
32 \\
64\end{array}$ & $\begin{array}{r}<8 \\
128 \\
64 \\
1024 \\
64 \\
1024\end{array}$ \\
\hline
\end{tabular}

$\mathrm{NT}=$ Not tested.

the wild and attenuated strains were found in the patas monkeys as in man: both the extent of virus excretion and the level of antibodies developed were reduced with the attenuated strain (Parkman et al., 1967; Meyer et al., 1968). It can be concluded that patas monkeys are as suitable as rhesus or African green monkeys for studies on rubella, particularly in the evaluation of vaccine strains of the virus.

\section{SUMMARY}

Erythrocebus patas monkeys share with certain other species of monkey and man a susceptibility to wild and attenuated strains of rubella virus. Overt clinical signs of infection do not occur, however, in this species.

\section{REFERENCES}

Cabasso, V. J., Stebbins, M. R., Kare- 1967. J. Lab. Clin. Med., 70, 429.

litz, S., Cerini, C. P., Ruegsegger,

J. M., AND Stillerman, M. 
CARver, D. H., Seto, D. S. Y., Marcus, 1967. J. Virol., 1, 1089. P. I., AND RODRIGUES, L.

Cotlier, E., Fox, J., Bohigan, G., 1968. Nature, Lond., 217, 38. Beaty, Claudia, and Du Pree, A.

Krugman, S., Ward, R., Jacobs, 1953. J. Amer. Med. Assoc., 151, 285. KATHRYN G., AND LAZAR, $M$.

Meyer, H. M., Parkman, P. D., 1968. Amer. J. Dis. Child., 115, 648. HobBins, T. E., AND ENNIS, F. A.

OXFORD, J. S.

. 1967. J. Immun., 98, 697.

Parkman, P. D., Meyer, H. M., Hopps, 1967. I Int. Conf. Vaccines Viral Rickettsial H. E., AND KIRSCHSTEIN, R. L. Dis., Washington 1966. Pan Amer. Hlth Org. Scient. Publ. no. 147, pp. 381 and 390.

Parkman, P. D., Phillips, P. E., 1965. J. Immun., 95, 743. Kirschstein, R. L., AND MeYER, H. M., $\mathrm{J}_{\mathbf{R}}$

SeVer, J. L., Meier, G. W., Windle, 1966. J. Infect. Dis., 116, 21. W. F., SchIFF, G. M., MoNif, G. R., AND FABIYI, A.

Sigurdardottir, B., Givan, Kathleen 1963. Canad. Med. Assoc. J., 88, 128. F., Rozee, E. R., AND Rhodes, A. J.

Stewart, G. L., Parkman, P. D., Hopps, 1967. New Engl. J. Med., 276, 554. H. E., Douglas, R. D., Hamilton, Judith P., AND Meyer, H. M., JR 